\author{
Anna Szczęsny \\ Warszawa
}

\title{
CZY MOŻNA SIĘ UCZYĆ NA (CUDZYCH) BŁĘDACH? \\ Z PROBLEMATYKI NAUCZANIA TŁUMACZENIA PISEMNEGO
}

\begin{abstract}
Zarys treści: Tekst poświęcony jest wybranym problemom dydaktyki tłumaczenia pisemnego na początkowym etapie nauczania. Autorka rozważa celowość analizy opublikowanych w Internecie tłumaczeń (tekstów krajoznawczych informacyjno-perswazyjnych) jako ilustracji typowych trudności przekładowych, skupiając się na błędach i mechanizmach ich powstawania. Ukierunkowana krytyka opublikowanego przekładu wydaje się dobrym - z punktu widzenia dydaktyki - wstępem do analizy i oceny tłumaczeń przygotowanych przez studentów. Istotnym elementem rozważań jest ponadto zagadnienie umiejętnego korzystania z zasobów internetowych jako źródła informacji potrzebnych przyszłym tłumaczom (wiarygodność źródeł, poprawność językowa).
\end{abstract}

Nie dojrzysz przecie twarzy

twarza w twarz.

Wielkie - $z$ dystansu się dostrzega ${ }^{1}$

Cwego czasu Monteskiusz w swoich Listach perskich zaproponował spojrzeUnie z dystansu, okiem Innego na rodzimą kulturę, obyczajowość, system polityczny. Być może i w przypadku tłumaczenia nie od rzeczy byłoby przyjrzenie się temu, co własne, dobrze znane (tekst w języku polskim) z perspektywy Innego (tłumacza, który jest rodzimym użytkownikiem innego języka)? Taka optyka uwydatnia to, co na co dzień niedostrzegalne, bo swojskie, za-

${ }^{1}$ Siergiej Jesienin - z wiersza List do kobiety. 
tem umyka naszej uwagi. Stąd pewna propozycja dydaktyczna, którą najlepiej byłoby wykorzystać na początkowym etapie kursu tłumaczenia pisemnego (w Instytucie Lingwistyki Stosowanej UW ma to miejsce na trzecim roku studiów).

O tym, że warto zajmować się na zajęciach nie tylko omawianiem domowych wariantów przygotowanych przez studentów, nie trzeba chyba nikogo przekonywać. Jeden z uznanych metodyków i praktyków tłumaczenia pisemnego Dmitrij Jermołowicz (Moskiewski Państwowy Uniwersytet Lingwistyczny) pisał na ten temat już 20 lat temu (Jermołowicz 1987), przytaczając istotne argumenty. Po pierwsze - tłumaczenia domowe studentów, nierzadko wykonywane w pośpiechu, wymagają różnorodnych poprawek, wśród których o ileż częściej niż z ostateczną redakcją tekstu mamy do czynienia z korektą poważnych błędów językowych oraz tłumaczeniowych, wynikających np. z niezrozumienia tekstu wyjściowego. Po drugie - sprawdzenie przez wykładowcę $\mathrm{w}$ toku zajęć wszystkich wariantów jest praktycznie niemożliwe, co zazwyczaj skutkuje tym, że studenci rezygnują z własnych pomysłów, wykorzystując w końcowej wersji tekstu te zatwierdzone na zajęciach. No i wreszcie element psychologiczny: jakakolwiek rzeczowa, dobrze uargumentowana krytyka wobec tekstu bywa postrzegana subiektywnie - i to niezależnie od tego, czy ocenia wykładowca, czy też studenci z grupy. Ci z kolei raczej niechętnie wypowiadają krytyczne opinie na temat prac kolegów, zwłaszcza na pierwszych zajęciach. Oczywiście ani Jermołowicz, ani żaden dydaktyk tłumaczenia nie neguje sensowności najpopularniejszej, zwyczajowej formy pracy - postuluje jedynie jej rozsądne urozmaicenie. Co zatem proponuje? Omawianie konkretnych tekstów paralelnych - w jego terminologii oznacza to tekst oryginału i opublikowanego przekładu, który a priori uznajemy za poprawny. Wnikliwa analiza translacyjna (tu warto na początku podpowiedzieć studentom, na które fragmenty powinni zwrócić szczególną uwagę) pozwala wyłowić bądź to niepoprawne kolokacje, bądź elementy tautologiczne czy w jakikolwiek sposób nadmiarowe, nieścisłości terminologiczne czy sformułowania niezręczne stylistycznie lub nieadekwatne ze względu na modalność tekstu lub jego specyfikę gatunkową. Rzecz jasna, warto podkreślić również szczególnie udane rozwiązania translatorskie, jednak niewątpliwie z dydaktycznego punktu widzenia lepsze są przykłady negatywne, bo wyzwalają większą aktywność studentów. Konkludując, Jermołowicz stwierdza, że wspólne poprawianie niedoskonałości przekładu jest zarazem efektywną formą nauczania tłumaczenia w ogóle, ponieważ uświadamia studentom, że czym innym jest wstępny etap tłumaczenia, przygotowanie surowej wersji tekstu, a czym innym jest jego adiustacja i ostateczna redakcja. Ponad- 
to wszyscy koncentrują się na jednym, konkretnym tekście, który wymaga analizy, oceny, udoskonalenia. I wreszcie aspekt psychologiczny: zawsze łatwiej zobaczyć przysłowiowe źdźbło trawy w cudzym oku niż belkę we własnym, łatwiej krytykować cudze potknięcia, niż zauważyć własne. $Z$ drugiej strony - skoro potrafimy surowo i drobiazgowo ocenić cudze poczynania, nie zawsze udane, może łatwiej będzie samemu poddać się krytyce i znieść negatywną ocenę, $\mathrm{z}$ większą pokorą potraktować swoje porażki. To może być mechanizm pozytywnego wzmocnienia. Zwłaszcza że wpadki zdarzają się nawet mistrzom.

Moja propozycja pracy z tekstem tłumaczonym na zajęciach dotyczy innego etapu kształcenia (u Jermołowicza - zaawansowany, tu - początkowy), a ponadto akcentuje inne fazy pracy tłumacza, nie tylko adiustację czy redakcję. Schemat wygląda następująco:

1. Lektura tekstu tłumaczonego na język polski jako samoistnego, bez żadnych odwołań do oryginału, z zaznaczeniem wszelkich niezręczności, sformułowań odbieranych jako niepoprawne bądź przynajmniej dziwne, niezrozumiałe, obce.

2. Pytanie o charakter tekstu - o czym te elementy mogą świadczyć? Tu warto zaanonsować koncepcję trzech poziomów „obcości” według R. Lewickiego (2000), koncentrując się na "poziomie błędu”, a także odwołać się do pojęcia „charakteru przekładowego tekstu” - za A. Legeżyńską (1986) - który może świadczyć o nieudolności tłumacza.

3. Pytanie o język oryginału. Najlepiej skupić się na tych elementach tekstu, przez które „prześwituje” tekst wyjściowy - to wychodzące od konkretu wprowadzenie $\mathrm{w}$ problematykę interferencji w przekładzie (zagadnienie znane studentom $\mathrm{w}$ zarysie $\mathrm{z}$ kursu glottodydaktyki).

4. Szczegółowa analiza wyodrębnionych elementów, propozycja korekty: sprzyjający moment na refleksję nad mechanizmami powstawania błędów (podkreślam najczęstsze problemy konfrontacji przekładowej rosyjsko-polskiej, zob. np. Kozłowska 2001), a na metapoziomie - na przywołanie klasyfikacji błędów w tłumaczeniu (np. Dzierżanowska 1988, Kozłowska 2001, Hejwowski 2001 i 2004).

5. Odwołanie się do oryginału, weryfikacja słuszności (lub nie) pierwotnych przypuszczeń co do odpowiednich fragmentów tekstu wyjściowego.

6. Wyjaśnienie kwestii spornych, błędów i wątpliwości, których zauważenie byłoby niemożliwe bez odwołania się do oryginału. Szczególną uwagę warto zwrócić na nieścisłości terminologiczne, wątpliwości dotyczące realiów, przypadki nielogiczności, niespójności, ewentualne błędy interpretacji. Jeśli zachodzi taka potrzeba, powinno się wskazać błędy w tekście oryginal- 
nym i udzielić ogólnych wskazówek w kwestii ich poprawiania (można zainicjować dyskusję na temat granic ingerencji tłumacza, odsyłając do literatury fachowej, zarazem proponując rozstrzygnięcie na konkretnym przykładzie).

7. Szersze omówienie obecnych w konkretnym tekście problemów, wymagających wiedzy metatranslacyjnej: oceny wiedzy potencjalnego odbiorcy, wyboru techniki przekładowej w odniesieniu do odbiorcy, sytuacji oraz celu tekstu (zazwyczaj dyskusja na temat różnych rozwiązań w odniesieniu do nazw własnych, analiza możliwości ich zastosowania w danym tekście, argumentacja wyboru; ponadto refleksja natury stylistycznej - określenie ogólnego wydźwięku tekstu (jego modalności), jego właściwości stylistycznych).

8. Na zakończenie - przygotowanie poprawionej wersji tekstu (korekta, redakcja) lub przetłumaczenie go na nowo z pełną świadomością trudności, które musi pokonać tłumacz (nie jest to niezbędny punkt programu, ale warto go zrealizować).

Na marginesie dodam, że w obecnie obowiązującym oraz w przygotowanym do wdrożenia nowym programie studiów (dwustopniowych) nie ma odrębnych ćwiczeń $\mathrm{z}$ translatoryki, zatem zagadnienia teoretyczne znane z wykładu warto właśnie w toku zajęć propedeutycznych przełożyć na konkretną parę językową konfrontowaną w tłumaczeniu.

Większe fragmenty tekstów tłumaczonych na język polski, poddanych analizie zamieszczam $\mathrm{w}$ aneksach, natomiast wybrane $\mathrm{z}$ nich przykłady zilustrują najbardziej interesujące czy wymagające szczególnej uwagi przypadki błędów, o których będzie mowa poniżej. Jeden z tekstów został przetłumaczony z włoskiego (w grupach, w których był omawiany, nikt ze studentów nie znał tego języka), drugi zaś - $\mathrm{z}$ rosyjskiego. Tekst nr 1 miał być swoistym punktem odniesienia dla tekstu nr 2, obrazującym specyfikę problemów tłumaczeniowych w konkretnej parze języków.

Oczywiście niezbędnym narzędziem analizy jest jakaś klasyfikacja błędów w tłumaczeniu. Nie proponuję własnej - odwołuję się do kilku uznanych, z pełną świadomością tego, jak trudno jest błędy w tłumaczeniu ująć $\mathrm{w}$ jednolite ramy z zachowaniem absolutnie rozłącznych kategorii. Na przykład w świetle podziału zaproponowanego przez Z. Kozłowską (2001: 138-140) błędy językowe mogą występować zarówno w tekstach oryginalnych, jak i tłumaczonych - niemniej przyczyną większości z nich jest interferencja, która poza sytuacją konfrontacji przekładowej nie ma (czy raczej nie powinna mieć) „mocy sprawczej”. 


\section{Błędy w tłumaczeniu (na język ojczysty) w ujęciu tekstologicznym:}

\section{Językowe}

- Widoczne bez konfrontacji z ory- - Wykrywalne w konfrontacji z oryginałem

- Mogą, ale nie muszą być sympto- - Są symptomem przekładowości mem przekładowości - Główne przyczyny: niedostatecz-

- Główny mechanizm - interferen- na kompetencja językowa i kultucja rowa, niedostateczna wiedza ogólziomach (ortograficzne, leksykalne, pośpiech, niedbalstwo frazeologiczne, słowotwórcze, fleksyjne, składniowe etc.)

Jak widać z powyższego zestawienia, zarówno te językowe, jak i tłumaczeniowe $\mathrm{w}$ węższym rozumieniu są de facto błędami występującymi właśnie w tłumaczeniu. Co więcej, pewne mechanizmy działają równocześnie, co daje w rezultacie konstrukcje wielopiętrowe: tak np. błędna nazwa własna (do tej kwestii jeszcze powrócę) Wielki Dwór Pietergofskij jest zarazem błędem tłumaczeniowym (niedostateczna wiedza), jak i językowym - leksykalnym (dwór zamiast pałac, faux ami) oraz słowotwórczym (przeniesienie modelu Pietergofskij w transkrypcji, bez retuszu).

W koncepcji K. Hejwowskiego (2001: 149-159, 2004: 124-149) decydującym kryterium klasyfikacyjnym jest etap, na którym błąd powstaje.

\section{Błędy w tłumaczeniu (na język ojczysty) w ujęciu procesualnym:}

- Błędy tłumaczenia syntagmatycznego (niewłaściwy dobór odpowiedników, faux amis, kalki na wszystkich poziomach, bezzasadne rekonstrukcje).

- Błędy interpretacji (niedostateczna znajomość języka oryginału - pomylenie syntagm, ram czasownikowych; niedostateczna wiedza - złe odczytanie scenariusza; błędne rozpoznanie modalności tekstu, intencji autora).

- Błędy realizacji (niewłaściwa ocena wiedzy odbiorców, podtłumaczenie, błędy języka docelowego - ojczystego; niedostateczna wiedza ogólna lub specjalistyczna).

- Błędy metatranslacyjne (nieznajomość podstawowych zasad tłumaczenia - niewłaściwy dobór techniki translacyjnej, bezzasadne opuszczenia, dodatki, poprawianie bądź niepoprawianie oryginału, nieadekwatny paratekst, podwójne wersje). 
W świetle tej klasyfikacji analizowany wyżej przykład Wielki Dwór Pietergofskij byłby błędem tłumaczenia powierzchniowego (kalka słowo po słowie), ale zarazem błędem realizacji (twór niezrozumiały) i metatranslacyjnym (brak wiedzy o tym, czym jest proces tłumaczenia, co należy robić z nazwami własnymi w przekładzie).

Poniżej prezentuję wybrane błędy (kolejno z obu tekstów), które warto przeanalizować i skomentować ze studentami, proponując zarazem korektę.

Tabela 1. Wybrane błędy z tekstu nr 1 (opis miast włoskich)

\begin{tabular}{|c|c|c|}
\hline Typ błędu & Fragment tekstu & Propozycja korekty, komentarz \\
\hline \multirow{3}{*}{$\begin{array}{l}\text { Błędy tłumacze- } \\
\text { nia powierzchnio- } \\
\text { wego: leksykalne }\end{array}$} & $\begin{array}{l}\text { - uprzywilejowanym miejscem } \\
\text { każdego turysty }\end{array}$ & $\begin{array}{l}\text { - szczególnym, wyjątkowym dla } \\
\text { każdego }\end{array}$ \\
\hline & $\begin{array}{l}\text { - nadaje rzeczywista wyjątko- } \\
\text { wość }\end{array}$ & - prawdziwa wyjątkowość \\
\hline & $\begin{array}{l}\text { - otwarcie na lagunę w kacie po- } \\
\text { tudniowo-wschodnim }\end{array}$ & $\begin{array}{l}\text { - w zakątku południowo- } \\
\text {-wschodnim }\end{array}$ \\
\hline \multirow{2}{*}{$\begin{array}{l}\text { Błędy tłumacze- } \\
\text { nia powierzchnio- } \\
\text { wego: leksykalno- } \\
\text { słowotwórcze }\end{array}$} & - nieporównywalny całokształt & $\begin{array}{l}\text { - niemajacy sobie równych, nie- } \\
\text { zrównany }\end{array}$ \\
\hline & $\begin{array}{l}\text { w miastach wschodnich wcho- } \\
d z a c y c h w \text { jej posiadtość }\end{array}$ & $\begin{array}{l}\text { posiadanie - (wybór niewłaści- } \\
\text { wych derywatów - paronimia) }\end{array}$ \\
\hline \multirow{5}{*}{$\begin{array}{l}\text { Błędy tłumacze- } \\
\text { nia powierzchnio- } \\
\text { wego: kolokacje }\end{array}$} & - gołębie przepełniaja plac & - wypetniają \\
\hline & $\begin{array}{l}\text { - dookoła nowych placów bu- } \\
\text { dowlanych }\end{array}$ & - placów budowy \\
\hline & - gościć nowe realizacje & - stać się, być miejscem³ \\
\hline & - podbój Konstantynopola & - zdobycie Konstantynopola \\
\hline & $\begin{array}{l}\text { - kawiarnie Wenecji aktywne az } \\
\text { do końca XVII wieku }\end{array}$ & - czynne, działajace a $\dot{z}$ do... \\
\hline \multirow{2}{*}{$\begin{array}{l}\text { Błędy tłumaczenia } \\
\text { powierzchniowe- } \\
\text { go: chybione me- } \\
\text { tafory, zbyt duże } \\
\text { skróty logiczne }\end{array}$} & $\begin{array}{l}\text { - turystów z całego świata, za- } \\
\text { nurzajacych się w ogromnej } \underline{\text { ilo- }} \\
\text { ści gotębi }\end{array}$ & $\begin{array}{l}\text { - jeśli z tym czasownikiem } \\
\text { i metaforycznie, to } w \text { morzu go- } \\
\text { tẹbi }\end{array}$ \\
\hline & $\begin{array}{l}\text { - z przyjściem imperium } \\
\text { i z powiększajaca się ludnościa }\end{array}$ & $\begin{array}{l}\text { - wraz ze wzrostem liczby lud- } \\
\text { ności (zbyt duży skrót) }\end{array}$ \\
\hline
\end{tabular}

2 Tu zauważalna trudność systemowa, istniejąca w kontraście polsko-włoskim - wybór odpowiedniej formacji przedrostkowej.

${ }^{3}$ Gościć - w odniesieniu do rzeczowników żywotnych, sugeruje tymczasowość; nawet jako metafora - nieudane zastosowanie. 


\section{Cd. tabeli 1}

\begin{tabular}{|c|c|c|}
\hline \multirow{3}{*}{$\begin{array}{l}\text { Błędy morfolo- } \\
\text { giczne - realiza- } \\
\text { cji (wybór nie- } \\
\text { właściwych form } \\
\text { deklinacyjnych, } \\
\text { wyrażeń przyim- } \\
\text { kowych) }\end{array}$} & $\begin{array}{l}\text { - bazylika była wielka duma } \\
\text { Wenecjanów } \\
\text { - kościół poświęcony do prze- } \\
\text { chowywania relikwi } \\
\text { - co nadaje rzeczywista wyjąt- } \\
\text { kowość temu placu }\end{array}$ & $\begin{array}{l}\text { - zarówno przypadek Wene- } \\
\text { cjan, jak i relikwii czy placowi } \\
\text { świadczyć może o nierozpozna- } \\
\text { niu właściwego paradygmatu lub } \\
\text { przypadka - interferencja we- } \\
\text { wnętrzna (w języku docelowym) }\end{array}$ \\
\hline & $\begin{array}{l}\text { - stare forum nie wystarczało } \\
{[\ldots], \text { dlatego powiększono go }}\end{array}$ & $\begin{array}{l}\text { - je nierozpoznanie rodzaju za- } \\
\text { imka }\end{array}$ \\
\hline & $\begin{array}{l}\text { - zbudowany w miejscu wcześ- } \\
\text { niej istniejącego kościoła }\end{array}$ & 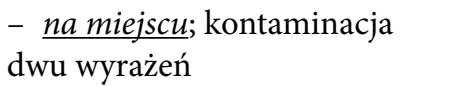 \\
\hline \multirow{4}{*}{$\begin{array}{l}\text { Błędy realizacji - } \\
\text { składnia (skutek } \\
\text { dążenia do lako- } \\
\text { niczności) }\end{array}$} & $\begin{array}{l}\text { - zbudowana w stylu oriental- } \\
\text { nym, pokryta jest pięcioma } \underline{\text { ko- }} \\
\text { pułami bizantyjskimi i bardzo } \\
\text { bogata fasada, z pięcioma porta- } \\
\text { lami ozdobionymi w cenne mar- } \\
\text { mury i rzeźby romańskie }\end{array}$ & $\begin{array}{l}\text { - pokryta jest pięcioma kopuła- } \\
\text { mi, posiada bogata fasadę z pię- } \\
\text { cioma portalami, która zdobia } \\
\text { cenne marmury i rzeźby romań- } \\
\text { skie (skutek nadmiernej konden- } \\
\text { sacji - dwie kolokacje z imiesło- } \\
\text { wem, błąd rekcji - powinno być } \\
\text { ozdobiony czym) }\end{array}$ \\
\hline & $\begin{array}{l}\text { - gromadzono wszystkie naj- } \\
\text { cenniejsze skarby odkryte w mia- } \\
\text { stach wschodnich wchodzacych } \\
\text { w jej posiadłość, podobnie jak } \\
\text { podbój Konstantynopola } \\
\end{array}$ & $\begin{array}{l}\text { - zbyt wielki skrót, stąd niezro- } \\
\text { zumiałość: powinno być np. po- } \\
\text { dobnie jak te zdobyte w wyniku } \\
\text { zajęcia Konstantynopola }\end{array}$ \\
\hline & $\begin{array}{l}\text { - Lecz tym co nadaje rzeczywi- } \\
\text { sta wyjątkowość temu placu to } \\
\text { przede wszystkim }\end{array}$ & $\begin{array}{l}\text { - skutek kontaminacji dwu po- } \\
\text { dobnych znaczeniowo struktur: } \\
\text { tym, co ..., jest oraz to, co..., to }\end{array}$ \\
\hline & $\begin{array}{l}\text { - Bazylika była zawsze wielka } \\
\text { duma Wenecjanów, symbolem } \\
\text { wielkości Republiki, gdzie gro- } \\
\text { madzono wszystkie najcenniej- } \\
\text { sze skarby }\end{array}$ & $\begin{array}{l}\text { - dwuznaczność zaimka anafo- } \\
\text { rycznego (lepsze odrębne zda- } \\
\text { nie, nawet z powtórzeniem lek- } \\
\text { sykalnym lub synonimem np. } \\
\text { w tej świątyni gromadzono...) }\end{array}$ \\
\hline \multirow{2}{*}{$\begin{array}{l}\text { Będy tłumacze- } \\
\text { niowe - meta- } \\
\text { translacyjne (na- } \\
\text { zwy własne) }\end{array}$} & $\begin{array}{l}\text { - Cezara, Augusta, Traiano, } \\
\text { Nerva i Wespasjana }\end{array}$ & $\begin{array}{l}\text { - Trajana, Nerwy (Nervy), Ok- } \\
\text { tawiana Augusta - nieznajo- } \\
\text { mość odpowiednika uznanego, } \\
\text { rekonstrukcja bez retuszu orto- } \\
\text { graficzno-morfologicznego }\end{array}$ \\
\hline & $\begin{array}{l}\text { Odgraniczony }[. . .] \text { od pótnocy } \\
\text { urzędem Procuratie Vecchie (od- } \\
\text { budowane w końcu XVI wieku). } \\
{[\ldots] \text { Pod partykami obu proku- }} \\
\text { ratur }\end{array}$ & $\begin{array}{l}\text { - brak konsekwencji: rekon- } \\
\text { strukcja, a następnie wersja ge- } \\
\text { neralizująca tłumaczona }\end{array}$ \\
\hline
\end{tabular}


Nietrudno zauważyć, że w tekście tłumaczonym zdecydowanie dominują błędy tłumaczenia powierzchniowego, zwłaszcza leksykalne; stosunkowo niewiele jest potknięć morfologicznych (tu przykłady interferencji wewnętrznej). Błędy składniowe wynikają głównie $z$ natłoku informacji i determinantów oraz dążenia do skrótowości (konwencja gatunku). Stricte tłumaczeniowe przejawiają się głównie w sferze nazw własnych: choć w całym tekście widać dość dobrą znajomość ekwiwalentów uznanych, to jednak tłumacz potknął się na imionach cesarzy. Te właśnie elementy w największym stopniu zdradzają język wyjściowy.

\section{Tabela 2. Wybrane błędy z tekstu nr 2 (wycieczka do Sankt Petersburga)}

\begin{tabular}{|c|c|c|}
\hline Typ błędu & Fragment tekstu & Propozycja korekty, komentarz \\
\hline \multirow{6}{*}{$\begin{array}{l}\text { Błędy tłumaczenia } \\
\text { powierzchniowego: } \\
\text { leksykalne, głów- } \\
\text { nie faux amis i pa- } \\
\text { ronimy }\end{array}$} & $\begin{array}{l}\text { - Petersburg nie na darmo zwa- } \\
\text { ny jest }\end{array}$ & $\begin{array}{l}\text { - nie bez racji, nieprzypadkowo, } \\
\text { stusznie }\end{array}$ \\
\hline & $\begin{array}{l}\text { - w rzeczywistości jest jednym } \\
\text { z najpiękniejszych miast świata }\end{array}$ & $\begin{array}{l}\text { - rzeczywiście, } w \text { istocie, faktycznie } \\
\text { (prawdopodobne pomylenie в са- } \\
\text { мом деле, на самом деле) }\end{array}$ \\
\hline & $\begin{array}{l}\text { - Dziedziniec Dworski, Dwór Zi- } \\
\text { mowy }\end{array}$ & - pałacowy, pałac \\
\hline & - Zalew Fiński & - Zatoka Fińska \\
\hline & - rezydencji rosyjskich imperialistów & - imperatorów, carów \\
\hline & $\begin{array}{l}\text { - Jekateryniński Dwór } z \text { odzyska- } \\
\text { nym umeblowaniem }\end{array}$ & $\begin{array}{l}\text { - zwyszukanym umeblowaniem - } \\
\text { faux ami, do ustalenia po odwoła- } \\
\text { niu się do oryginału }\end{array}$ \\
\hline \multirow{3}{*}{$\begin{array}{l}\text { Błędy tłumaczenia } \\
\text { powierzchniowego: } \\
\text { leksykalne (słowni- } \\
\text { ctwo specjalistycz- } \\
\text { ne - nieświadomość } \\
\text { różnic terminolo- } \\
\text { giczno-klasyfikacyj- } \\
\text { nych) }\end{array}$} & - muzeum-rezerwat & $\begin{array}{l}\text { - muzeum na wolnym powietrzu, } \\
\text { muzeum typu skansen }\end{array}$ \\
\hline & - sztuka parkowo-ogrodowa & $\begin{array}{l}\text { - sztuka parkowa, szerzej: architek- } \\
\text { tura krajobrazu }\end{array}$ \\
\hline & - pierwotna sztuka & - sztuka prehistoryczna \\
\hline \multirow{3}{*}{$\begin{array}{l}\text { Błędy tłumaczenia } \\
\text { powierzchniowego: } \\
\text { kolokacje }\end{array}$} & $\begin{array}{l}\text { - Niżnyj Park, gdzie latem pracuja } \\
173 \text { fontanny, a zima } \underline{Z} \underline{\text { muzeów }}\end{array}$ & $\begin{array}{l}\text { - działaja, sa czynne (interferencja } \\
\text { - przekalkowane niepoprawne po- } \\
\text { łączenie wyrazowe) }\end{array}$ \\
\hline & $\begin{array}{l}\text { - obszerna kolekcje sztuki zachod- } \\
\text { niej }\end{array}$ & - bogatą kolekcje \\
\hline & $\begin{array}{l}\text { - Ermitaż liczy } 3 \text { miliony ekspona- } \\
\text { tów }\end{array}$ & $\begin{array}{l}\text { - kolekcja Ermitażu liczy, zbiory } \\
\text { Ermitażu licza (zbyt duży skrót) }\end{array}$ \\
\hline
\end{tabular}




\section{Cd. tabeli 2}

\begin{tabular}{|c|c|c|}
\hline \multirow{2}{*}{$\begin{array}{l}\text { Błędy morfolo- } \\
\text { giczne - realizacji } \\
\text { (w tym słowotwór- } \\
\text { cze) }\end{array}$} & - Admiralstwo & $\begin{array}{l}\text { - Admiralicja (interferencja we- } \\
\text { wnętrzna, zastosowanie mode- } \\
\text { lu słowotwórczego, produktywnego } \\
\text { w polszczyźnie, ale niepoprawnego } \\
\text { w tej konkretnej formacji) }\end{array}$ \\
\hline & $\begin{array}{l}\text { - gdzie mieści się ponad } 100 \text { obiek- } \\
\text { tów architektonicznych, dworów, ka- } \\
\text { miennych pawilonów, pomników } \\
\text { i rzeźby parkowej }\end{array}$ & $\begin{array}{l}\text { - rzeźb parkowych- użycie cha- } \\
\text { rakterystycznej dla rosyjskiego lp } \\
\text { w znaczeniu zbiorowym (nie jest } \\
\text { to w rosyjskim przypadek singula- } \\
\text { ria tantum, a jedynie zastosowanie } \\
\text { analogiczne do form oznaczających } \\
\text { zbiór jednorodnych przedmiotów) }\end{array}$ \\
\hline \multirow{5}{*}{$\begin{array}{l}\text { Błędy realizacji - } \\
\text { składnia (w tym } \\
\text { morfosyntaktyka } \\
\text { i szyk) }\end{array}$} & $\begin{array}{l}\text { - Odwiedziwszy Petersburg może- } \\
\text { cie ujrzeć }\end{array}$ & $\begin{array}{l}\text { - Odwiedzajac Petersburg - nie- } \\
\text { odpowiedni wybór imiesłowu, nie- } \\
\text { dostosowanie do kontekstu skła- } \\
\text { dniowego - w konsekwencji błąd } \\
\text { logiczny }{ }^{4}\end{array}$ \\
\hline & - do Miasta na Niewie & $\begin{array}{l}\text { - miasta nad Newa - przekalkowa- } \\
\text { na z rosyjskiego konstrukcja loka- } \\
\text { tywna } \mathrm{Ha}+\mathrm{Ms} . \text { odpowiadająca pol- } \\
\text { skiemu } n a d+\mathrm{N} \text {. }\end{array}$ \\
\hline & $\begin{array}{l}\text { - Dziś możecie pojechać do jedne- } \\
\text { go z najpiękniejszych miejsc-Pie- } \\
\text { trodworiec }\end{array}$ & $\begin{array}{l}\text { - do Pietrodworca - nieuzasadnio- } \\
\text { ne użycie formy nieodmienionej }\end{array}$ \\
\hline & $\begin{array}{l}\text { - Wspaniała wycieczka do miasta } \\
\text { Puszkin - muzeum-rezerwat „Car- } \\
\text { ska Wioska” - byłej rezydencji rosyj- } \\
\text { skich imperialistów }\end{array}$ & $\begin{array}{l}\text { - do Carskiego Sioła(do kompleksu } \\
\text { muzealnego Carskie Sioło) - apozy- } \\
\text { cja w formie nieodmienionej, co po- } \\
\text { woduje niezrozumiałość zdania }\end{array}$ \\
\hline & $\begin{array}{l}\text { - pierwotna sztukę, folklorystyczny } \\
\text { koncert, Pótnocnym Palmirem, Pót- } \\
\text { nocną Wenecja }\end{array}$ & $\begin{array}{l}\text { - sztukę prehistoryczna, koncert } \\
\text { folklorystyczny, Palmira Pótnocy, } \\
\text { Wenecja Pólnocy - szyk przydaw- } \\
\text { ki przymiotnikowej z typową dla } \\
\text { rosyjskiego prepozycją wobec od- } \\
\text { miennych reguł w polszczyźnie, za- } \\
\text { stosowanie przydawki rzeczownej }\end{array}$ \\
\hline
\end{tabular}

ności.

${ }^{4}$ Co ciekawe, w oryginale również błędna forma uprzednia zamiast oczywistej współczes-

${ }^{5}$ Szyk przydawki stanowi szczególną trudność, zwłaszcza w przypadku nagromadzenia wielu określników i jest przyczyną najczęstszych błędów w konfrontacji przekładowej rosyjsko-polskiej. 


\section{Cd. tabeli 2}

\begin{tabular}{|c|c|c|}
\hline \multirow{2}{*}{$\begin{array}{l}\text { Błędy realizacji - } \\
\text { ortografia }\end{array}$} & $\begin{array}{l}\text { - możecie państwo wziać udziat... } \\
\text { W żadnym mieście w Europie Pót- } \\
\text { nocnej nie spotkacie Państwo takiej } \\
\text { liczby mostów }\end{array}$ & $\begin{array}{l}\text { - arbitralne stosowanie adresaty- } \\
\text { wów, ortografia - przypadkowa }\end{array}$ \\
\hline & - podróż do Miasta na Niewie & $\begin{array}{l}\text { - do miasta nad Newa nieuzasad- } \\
\text { niona wielka litera (w rosyjskim } \\
\text { symboliczne nazwy własne pisze się } \\
\text { wielką literą) }\end{array}$ \\
\hline \multirow{5}{*}{$\begin{array}{l}\text { Będy tłumaczenio- } \\
\text { we - metatranslacyj- } \\
\text { ne (nazwy własne) }\end{array}$} & $\begin{array}{l}\text { A. Dziedziniec Dworski, Dwór Zi- } \\
\text { mowy, Admiralstwo, Zalew Fiński, } \\
\text { „Carska Wioska”, Pótnocny Palmir, } \\
\text { Pótnocna Wenecja, Miasto na Niewie }\end{array}$ & $\begin{array}{l}\text { A. Plac Pałacowy, Pałac Zimowy, } \\
\text { Admiralicja, Zatoka Fińska, Carskie } \\
\text { Sioło, Palmira Pótnocy (tu także nie- } \\
\text { oczekiwana zmiana rodzaju grama- } \\
\text { tycznego), Wenecja Północy, miasto } \\
\text { nad Newa }\end{array}$ \\
\hline & $\begin{array}{l}\text { B. Wielki Dwór Pietergofskij, Niż- } \\
\text { nyj Park }\end{array}$ & $\begin{array}{l}\text { B. Wielki Pałac Piotrowy, w innych } \\
\text { wersjach pałac Piotra I; Park Dolny }\end{array}$ \\
\hline & C. Jekateryniński Dwór & $\begin{array}{l}\text { C. Pałac Katarzyny lub Pałac Jeka- } \\
\text { teryniński }\end{array}$ \\
\hline & D. W Pietergofskim Muzeum & D. zob. komentarz pod tabelą \\
\hline & $\begin{array}{l}\text { E. centrum „carskosielskogo an- } \\
\text { sambla” }\end{array}$ & $\begin{array}{l}\text { E. centrum kompleksu architekto- } \\
\text { nicznego Carskiego Sioła }\end{array}$ \\
\hline \multirow{4}{*}{$\begin{array}{l}\text { Błędy metatransla- } \\
\text { cyjne - rzeczowe, } \\
\text { logiczne, nieade- } \\
\text { kwatność kulturowa }\end{array}$} & - złoto sfinksów & $\begin{array}{l}\text { - błąd jest - jak się okazało - w sa- } \\
\text { mym oryginale; prawdopodobnie } \\
\text { chodziło o słynną kolekcję wyrobów } \\
\text { jubilerskich czyli złoto Scytów! }\end{array}$ \\
\hline & $\begin{array}{l}\text { - Ermitá̇ liczy } 3 \text { miliony ekspo- } \\
\text { natów }\end{array}$ & $\begin{array}{l}\text { - kolekcja, zbiór, ew. dział liczy, } \\
\text { zbiory liczq }\end{array}$ \\
\hline & $\begin{array}{l}\text { - Peterhof-Pietrodworiec, Pusz- } \\
\text { kin- „Carska Wioska” }\end{array}$ & $\begin{array}{l}\text { - Peterhof - Pietrodworiec, Puszkin } \\
\text { - Carskie Sioło Sioło (niegdyś jesz- } \\
\text { cze Dietskoje Sieło) - nieuwzględ- } \\
\text { nienie wiedzy odbiorcy wtórnego } \\
\text { na temat historycznych zmian nazw } \\
\text { miejscowości }\end{array}$ \\
\hline & $\begin{array}{l}\text { - Po przyjeździe i zakwaterowa- } \\
\text { niu się w jednym z wybranych przez } \\
\text { Was hoteli, możecie państwo wziąć } \\
\text { udział w w wycieczce } \\
\text { - Dziś możecie pojechać do jednego } \\
\text { z najpiękniejszych miejsc } \\
\text { (to zarazem płaszczyzna realizacji - } \\
\text { pomieszanie różnych rejestrów }\end{array}$ & $\begin{array}{l}\text { - Nieadekwatność form umotywo- } \\
\text { wanych kulturowo - absolutnie ar- } \\
\text { bitralne, niekonsekwentne stosowa- } \\
\text { nie form adresatywnych }\end{array}$ \\
\hline
\end{tabular}


Szczególną uwagę warto zwrócić na problem nazw własnych ${ }^{6}$ (zob. przedostatni wiersz tabeli powyżej). Mamy tu kilka absolutnie podręcznikowych przypadków:

A. Wszystkie wymienione tu przykłady tłumaczenia powierzchniowego dowodzą nieznajomości tzw. ekwiwalentów uznanych i podstawowej leksyki geograficznej (w przypadku Zatoki Fińskiej znów faux ami).

B. Tu z kolei mamy do czynienia z dziwaczną hybrydą: wyraz będący w nazwie hiperonimem został przetłumaczony, reszta zaś zatranskrybowana; sama transkrypcja (czy też rekonstrukcja) jako technika tłumaczeniowa ma bardzo wiele zalet, zwłaszcza w tekście o charakterze przewodnikowym - turysta $\mathrm{z}$ łatwością odnajdzie obiekt, jeśli potrafi wypowiedzieć jego nazwę w wersji brzmieniowo bliskiej oryginałowi, co przy barierze alfabetu jest istotne. W tym kontekście jednak takie rozwiązanie razi niekonsekwencją; można by zaproponować dublet: wersję tłumaczoną, a obok przybliżony zapis brzmienia.

C. To rozwiązanie lepsze niż poprzednie, po korekcie hiperonimu ( $p a$ $\nmid a c)$, bowiem mamy tu transkrypcję $\mathrm{z}$ retuszem, dostosowującym element obcy do polskiego systemu fleksyjnego (Jekateryniński) - tu warto przedyskutować ze studentami możliwe zastosowania konkurencyjnych rozwiązań $\mathrm{Pa}$ łac Katarzyny czy Pałac Jekateryniński - oba są akceptowalne, różnią się wymiarem pragmatycznym.

D. Przypadek najbardziej skomplikowany, a zatem i dobry materiał do dyskusji. To, co w oryginale zostało określone mianem Петергофский музей, nie jest oficjalną nazwą - obejmuje całość zabytków znajdujących się w Peterhofie. Można tu zaproponować kilka rozwiązań: przez analogię z podobnymi obiektami - zespół parkowo-pałacowy Peterhof, kompleks muzealny Peterhof czy po prostu wybrać inny odpowiednik referencjalny, zarazem generalizacjęnp. na terenie rezydencji bądź w Peterhofie.

E. Tłumacz najprawdopodobniej nie wiedział, co z tym fantem zrobić, zatem zastosował transkrypcję nazwy rosyjskiej i dla złagodzenia niezręczności zamknął ją w cudzysłów - to nieuzasadniona rekonstrukcja.

${ }^{6}$ Ponieważ problem nazw własnych w przekładzie będzie stale obecny w toku całego trzyletniego kursu ćwiczeń translacyjnych, warto go od samego początku zaakcentować bardzo mocno. Ciekawą propozycję - również w wymiarze teoretycznym - przedstawił wspominany już Jermołowicz w swej pracy Имена собственные: теория и практика межъязыковой передачи - do odpowiednich rozdziałów warto sięgnąć i polecam ją studentom. Oczywiście nie znajdą tam (choć to obszerna i systematyczna monografia) gotowych recept i rozwiązań wszystkich kwestii szczegółowych - wszak tłumaczymy teksty różnorodne gatunkowo, realizujące różne cele, przeznaczone dla różnych odbiorców. 
Przytoczone przykłady każą przypuszczać, że mamy do czynienia z tłumaczeniem na język obcy. W całym tekście dominują błędy powierzchniowe (przekład ewidentnie syntagmatyczny); praktycznie brak błędów mylnej interpretacji (co nie znaczy, że to się nie zdarza w językach blisko spokrewnionych), są natomiast błędy realizacji, które w dużej mierze są wynikiem mechanicznego, bezrefleksyjnego odwzorowania oryginału ${ }^{7}$. Stąd m.in. niewłaściwa ocena wiedzy odbiorców (brak powiązania pomiędzy Peterhof, Pietrodworiec, Carskie Sioło, Puszkin); błędy języka docelowego (przenoszenie wzorców ortograficznych oryginału, kłopoty z odmianą; błędy wynikające $\mathrm{z}$ braku wiedzy ogólnej (szczególnie widoczne na przykładzie nieznajomości odpowiedników uznanych nazw geograficznych i innych mikrotoponimów), wreszcie błędy metatranslacyjne (niepoprawienie oryginału, nieznajomość konwencji komunikacyjnych języka docelowego - niedbałe, nieprzemyślane użycie form grzecznościowych).

Gdybyśmy mieli oceniać jakość tłumaczeń zamieszczanych w Internecie i wiarygodność jego zasobów jedynie na podstawie omówionych tu tekstów, wnioski byłyby zatrważające. To może być dla studentów przykra konstatacja. Na szczęście sieć obfituje w przykłady pozytywne - jeden z nich przywołam.

$\mathrm{W}$ tekście oryginalnym w języku rosyjskim, opisującym zabytki ławry Troicko-Siergijewskiej, pojawia się następujące sformułowanie:

В 1476 году на месте деревянного храма псковские мастера возвели каменную Духовскую иерковъ. Духовская иерковь - необычайно стройное, легкое и устремленное ввысь сооружение. В основании храма расположена открытая звоннииа на шести круглых приземистых столбах. В пролетах звонницы на дубовых брусьях висят колокола ${ }^{8}$.

Nawet wyposażeni w najbogatszy słownik objaśniający nie znajdziemy takiego odpowiednika podkreślonego wyrażenia, którego użycie byłoby zgodne z logiką i zdrowym rozsądkiem - czyż możliwe jest usytuowanie dzwonnicy w fundamentach budynku? Dzięki lekturze innych tekstów internetowych na ten temat i obejrzeniu fotografii ${ }^{9}$ udało się stwierdzić, że chodziło o podstawę bębna kopuły, wieńczącej cerkiew. W tekście oryginalnym brakowało pełnej

${ }^{7} \mathrm{Na}$ zajęciach w jednej z grup padła nawet uwaga, że tekst przełożono przy pomocy tłumacza elektronicznego lub TMS, bez redakcji końcowej.

${ }^{8}$ Zob. http://www.towns.ru/towns/sergievposad.html (dostęp styczeń 2007).

9 Zob.http://mega.km.ru/GOLDENRING/gr_ring.asp?ContextString=101412\&CStr1=1010 00\&ParamParent=101400\&lang=rus (dostęp kwiecień 2007), http://www.zolotoe-koltso.ru/goroda _new/sergievposad/sergievposad_lavra_duzovskaya.php (dostęp kwiecień 2007). 
informacji (znów wynik dążenia do skrótowości). Jak widać na tak niewinnym z pozoru przykładzie, wiedza na temat świata przedstawionego w tekście, zwłaszcza jeśli mamy do czynienia z opisem wrażeń wizualnych, jest niezbędna.

\section{Wnioski: jaki może być pożytek z tej formy pracy?}

W naszym przekonaniu szczegółowa analiza opublikowanego przekładu pozwala osiągnąć cele szczegółowe, istotne z punktu widzenia dydaktyki translacji. Są to m.in.:

1. Wpajanie zasady umiejętnego (pełnego krytycyzmu) wykorzystania informacji pochodzących z zasobów internetowych: konieczność weryfikacji źródła, ocena jego rzetelności (tak faktograficznej, jak i językowej) - są tu przykłady negatywne, ale i pozytywne, warto dla równowagi posłużyć się jednymi i drugimi.

2. Uwrażliwienie - co szczególnie ważne w przypadku języków blisko spokrewnionych ze sobą (polski, rosyjski) - na mechanizm interferencji międzyjęzykowej, najwyraźniej obecnej na poziomie leksykalnym (zwłaszcza błędne kolokacje, co w największym stopniu dotyczy związków łączliwych, gdyż na idiomy studenci są dość mocno wyczuleni; fałszywi przyjaciele tłumacza; niewłaściwy dobór odpowiednika) oraz morfosyntaktycznym (rekcja, wyrażenia przyimkowe, szyk przydawki, konstrukcja zdań z imiesłowami, wskaźniki spójności tekstowej, głównie spójniki i wyrażenia spajające, wyrazy deiktyczne).

3. Wyeksponowanie jednego $\mathrm{z}$ najważniejszych - i uniwersalnych problemów tłumaczeniowych, jakim są nazwy własne, wstępne nakreślenie potencjalnych rozwiązań translatorskich - na początek w tekstach stosunkowo prostych (choć teksty ofert turystycznych wymuszają określone techniki ze względu na swój wymiar funkcjonalny - musimy wiedzieć, kiedy chodzi o walory poznawcze, a kiedy o informację praktyczną, żeby trafić do celu podróży), odniesienie możliwych technik do konkretnej sytuacji komunikacyjnej.

4. Zaznajomienie się $\mathrm{z}$ typowymi $\mathrm{w}$ danej parze językowej mechanizmami błędów, czy to językowych, czy to tłumaczeniowych w węższym rozumieniu. W tym kontekście na uwagę zasługuje często niedoceniany aspekt poprawnościowy (ortografia, interpunkcja, zawsze zgodne z normą języka docelowego), który bardzo rzutuje na odbiór i ostateczną ocenę jakości przekładu. 
5. Podkreślenie konieczności czerpania informacji o świecie przedstawionym, która pozwala zrozumieć jak najpełniej tekst (stworzyć właściwą bazę kognitywną), bo to etap warunkujący poprawny przekład. To pozwala wyeliminować ewentualne błędy w tekście wyjściowym - tu jednak poczynię zastrzeżenie: na wyższych latach studiów wprowadzamy w niuanse zagadnienia, ponieważ błędy w tekście wyjściowym mają swą wagę i nie powinny być bezwzględnie poprawiane ${ }^{10}$. Dążenie do absolutnej poprawności merytorycznej może zaprzepaścić wizję autorską - Nikołaj Garbowskij, który widzi analogię pomiędzy obrazem artystycznym a ekwiwalentem w tłumaczeniu, przestrzega przed pokusą pójścia na skróty wprost do sfery „nagich desygnatów"11. Warto również dodać i to, że nie cała wiedza tłumacza na temat powinna być za wszelką cenę w tekście wyeksponowana - do tego zobowiązuje lojalność tłumacza wobec autora (Tabakowska 1999). Być może jednak jest to temat do rozważań na etapie bardziej zaawansowanym niż propedeutyka tłumaczenia pisemnego.

6. Doskonalenie analizy translacyjnej m.in. poprzez potraktowanie tłumaczenia najpierw jako tekstu samoistnego. $\mathrm{W}$ dalszej kolejności następuje porównanie $\mathrm{z}$ oryginałem (i ewentualne wychwycenie innych błędów).

7. Podkreślenie znaczenia umiejętności adiustacji i redagowania tekstu, które są bardzo ważnymi etapami pracy tłumacza, nierzadko decydującymi w zasadniczym stopniu o ocenie jakości tłumaczenia. To umiejętność tym ważniejsza, że coraz więcej wydawnictw dziś traktuje tłumacza jako ostateczną i jedyną instancję, oszczędzając na redakcji merytorycznej i korekcie tekstu.

${ }_{10}$ Przykład za Anną Bednarczyk (2002: 56-57) - Pawła Hertza tłumaczenie wiersza Osipa Mandelsztama, w którym poprawił (wyeliminował) użyte przez autora określenie Ateny jako bogini morza.

${ }^{11} \mathrm{~W}$ tłumaczeniu nie chodzi wszak o bezpośrednie, powtórne odwzorowanie realnego obiektu w języku docelowym, które stanowi zbiór jego cech relewantnych i funkcjonujących w świadomości zbiorowej jakiejś społeczności, ale zarazem nie ma nic wspólnego z autorskim postrzeganiem tego obiektu, z obrazem artystycznym (Garbowskij). 


\section{Aneks 1}

\section{Tekst nr 1}

\section{Plac Świętego Marka}

Plac Świętego Marka jest sercem Wenecji, uprzywilejowanym miejscem każdego turysty przez nieporównywalny całokształt i niezrównane obecne zabytki. Plac ma formę trapezowatą i osiąga długość około 175 metrów, a w punkcie maksymalnej szerokości pomiaru około 80 metrów. Odgraniczony od wschodu Bazyliką św. Marka, a od północy urzędem Procuratie Vecchie (odbudowane w końcu XVI wieku), od zachodu pałacem napoleońskim łączącym obie prokuratury, który zbudowany został w XIX wieku w miejscu wcześniej istniejącego kościoła San Gemignano. Pod partykami obu Prokuratur, znajdują się niektóre historycznie kawiarnie Wenecji aktywne aż do końca XVIII wieku.

Lecz tym, co nadaje rzeczywistą wyjątkowość temu placu, jest przede wszystkim jego otwarcie na lagunę w kącie południowo-wschodnim, odgraniczone z jednej strony wysoką Dzwonnicą, a z drugiej przepięknymi arkadami Pałacu Książęcego. W tej otwartej i rozległej przestrzeni otoczonej historycznymi pałacami znajdziemy turystów z całego świata, zanurzających się w ogromnej ilości gołębi, które przepełniają Wenecję. [...]

Pierwszy kościół poświęcony do przechowywania cennych relikwii, został konsekrowany w 832 roku, ale konstrukcja tej Bazyliki pochodzi z XII wie$\mathrm{ku}$, zbudowana w stylu orientalnym, pokryta jest pięcioma kopułami bizantyjskimi i bardzo bogatą fasadą, z pięcioma portalami ozdobionymi w cenne marmury i rzeźby romańskie. [...]

Bazylika była zawsze wielką dumą Wenecjanów, symbolem wielkości Republiki, gdzie gromadzono wszystkie najcenniejsze skarby odkryte w miastach wschodnich wchodzących w jej posiadłość, podobnie jak podbój Konstantynopola. [...]

\section{Rzym}

[...] Z przyjściem imperium i z powiększającą się ludnością, $\mathrm{w}$ handlu, w dyplomacji, w dziełach uświetniających wielkość imperatorów, stare forum republikańskie nie wystarczało, by gościć nowe realizacje, dlatego powiększono go dookoła nowych placów budowlanych w następstwie przez Cezara, Augusta, Traiano, Nerva i Wespasjana oraz kolejno wzbogacono przez następnych imperatorów $[\ldots]^{12}$.

\footnotetext{
12 Źródło: http://www.capriweb.com.
} 


\section{Aneks 2}

\section{Tekst nr 2}

Przygotujemy Państwu wspaniałą podróż do Miasta na Niewie. Petersburg nie na darmo zwany jest Północnym Palmirem, Północną Wenecją, w rzeczywistości jest jednym z najpiękniejszych miast świata. W żadnym mieście w Europie Północnej nie spotkacie Państwo takiej liczby mostów. Odwiedziwszy Petersburg możecie ujrzeć wyjątkowe budowle, wspaniałe place, dwory, świątynie i wiele innych wyjątkowych miejsc.

Dzień 1. Po przyjeździe i zakwaterowaniu się w jednym z wybranych przez Was hoteli, możecie państwo wziąć udział w wycieczce po mieście, by ujrzeć jego atrakcje: Dziedziniec Dworski, Dwór Zimowy, Plac Dekabrystów, Admiralstwo, Twierdzę Pietropawłowską i wiele innych. Wieczorem czeka Państwa kolacja powitalna w restauracji rosyjskiej i folklorystyczny koncert.

Dzień 2. Dziś możecie pojechać do jednego z najpiękniejszych miejsc - Pietrodworiec. To letnia rezydencja carów rosyjskich - Wersal Wschodu, położona u wybrzeży Zalewu Fińskiego - perła sztuki rosyjskiej, miasto parków, dworów i fontann. W Pietergofskim Muzeum ujrzycie Wielki Dwór Pietergofskij z trzema wspaniałymi kaskadami, z których jedna upiększona jest wspaniałą fontanną „Samson”, Niżnyj Park, gdzie latem pracują 173 fontanny, a zimą 7 muzeów. [...]

Dzień 2. Wspaniała wycieczka do miasta Puszkin - muzeum-rezerwat „Carska Wioska” - byłej rezydencji rosyjskich imperialistów. To wyjątkowy zabytek architektury światowej i sztuki parkowo-ogrodowej wieków XVIII-XIX. Jego trzy parki zajmują 600ha, gdzie mieści się ponad 100 obiektów architektonicznych, dworów, kamiennych pawilonów, pomników i rzeźby parkowej. Najwspanialszym elementem centrum „carskosielskogo ansambla” jest Jekateryniński Dwór z odzyskanym umeblowaniem, sztuka dekoracyjno-użytkowa.

Dzień 3. [...] Ermitaż liczy 3 miliony eksponatów pochodzących z okresu od najdawniejszych czasów do współczesności. W 400 salach przedstawiono pierwotną sztukę, dzieła Egipcjan, sztukę antyczną, złoto sfinksów, obszerną kolekcję sztuki zachodniej i wiele innych. [... $]^{13}$

${ }_{13}$ Źródło: http://www.irkutsk-baikal.com. 


\section{Literatura}

Bednarczyk, A., 2002, Kulturowe aspekty przekładu literackiego, Katowice.

Dzierżanowska, H., 1988, Przekład tekstów nieliterackich, Warszawa.

Garbowskij, N. К. (Гарбовский, Н. К.), „Перевод - искусство”, http://www. native-english.ru/theory/manuals/ (dostęp styczeń 2007).

Hejwowski K., 2001, „Źródła błędów w tłumaczeniu na język ojczysty”, [w:] Język rodzimy a język obcy - komunikacja, przekład, dydaktyka, str. 149-159, Wydawnictwa Uniwersytetu Warszawskiego.

Hejwowski K., 2004, Kognitywno-komunikacyjna teoria przekładu, Warszawa. Jermołowicz, D. I. (Ермолович, Д. И.), 1987, „О практике редактирования в подготовке переводчиков", [w:] Тетради переводчика, выпуск 22, под ред. С. Ф. Гончаренко, Москва, s. 94-99.

Jermołowicz, D. I. (Ермолович, Д. И.), 2005, Имена собственные: теория и пракика межъязыковой передачи, Москва.

Kozłowska Z., 2001, „O błędach językowych w tekstach polskich przekładów", [w:] Język rodzimy a język obcy - komunikacja, przekład, dydakty$k a$, s. 137-147, Warszawa.

Legeżyńska A., 1986, Tłumacz i jego kompetencje autorskie, Warszawa.

Lewicki R., 2000, Obcość w odbiorze przekładu, Lublin.

Tabakowska E., 1999, O przekładzie na przykładzie. Rozprawa tłumacza z „Europa" Normana Daviesa, Kraków.

\section{Is it possible to learn from mistakes of others? From the problematics of translation teaching (summary)}

The paper addresses some selected issues of translation didactics at the first stage of academic instruction. The author considers the purpose of the analysis of translations published on the Internet (persuasive and informative texts). Such analysis uncovers typical translation problems, revealing errors and mechanisms of their occurrence. From the didactic point of view, the trained critics of a published translation seems to be a good step before the analysis and evaluation of texts translated by students. The main arguments for such form of work are as follows:

1. inculcation of the principles of competent usage of Internet as the source of information for future translators (reliability of information resources, linguistic correctness); 
2. sensitivization to mechanisms of cross-linguistic interference - which is particularly important in the case of typologically close languages, when language transfers are clearly present at both lexical and morphosyntactic levels;

3. familiarization with mechanisms of errors and of sensu stricto translation that are typical of a chosen pair of languages;

4. identification of proper names as one of the main problems of translation process; indication of possible solutions;

5. stressing the necessity to learn about the world presented in the original in order for better understanding of the text and the ability to build the "proper cognitive basis";

6. improvement of translational analysis (first, as of a self-contained text, then in reference to the original);

7. stressing the importance of layout and editing, which may be crucial in evaluating the quality of translation. 